\title{
KARAKTERISTIK BIOFISIK KOTA LANGSA, ACEH
}

\author{
Iswahyudi \\ Program Studi Agroteknologi Fakultas Pertanian Universitas Samudra \\ Email: iswahyudi@unsam.ac.id
}

\begin{abstract}
Abstrak
Secara umum sebagian besar wilayah Kota Langsa Langsa berada di daerah pesisir dengan iklim tropis yang tergolong ke dalam tipe iklim C (agak basah). Lerengnya didominasi oleh kelas lereng $0-8 \%$ dengan luas $18.371,17$ ha $(91,06 \%)$. Ordo tanahnya dapat digolongkan menjadi tiga, yaitu: histosol, entisol dan inceptisol. Ordo inceptisol mendominasi tanah di Kota Langsa dengan luas 10 558,39 ha (52,34\%). Tutupan lahan terluas adalah perkebunan dengan luas 5.574,48 ha (27,63\%). Sistem lahanya terdiri dari 4 (empat) jenis. Sistem lahan Bakunan (BKN) merupakan yang terluas ditemui dengan luasan 10 745,30 ha (53,26\%). Adapun geologi di Kota Langsa terdiri atas 4 (empat) formasi geologi, dimana formasi geologi Aluvium Muda (Qh) mempunyai luasan terluas dibandingkan formasi yang lain, dengan luas 12 977,64ha $(64,33 \%)$.
\end{abstract}

Kata Kunci: Iklim tropsi, ordo tanah, sistem lahan, geologi

\section{Pendahuluan}

Kota Langsa terletak di pesisir pantai timur Provinsi Aceh merupakan hasil pemekaran wilayah dari Kabupaten Aceh Timur pada tanggal 21 Juni 2001 berdasarkan Undang-Undang No. 3 Tahun 2001. Ibukotanya adalah Langsa Kota yang berjarak kurang lebih $400 \mathrm{~km}$ dari Kota Banda Aceh, Ibukota Provinsi Aceh. Kota Langsa sebelumnya berstatus Kota Administratif sesuai dengan Peraturan Pemerintah No. 64 Tahun 1991 tentang Pembentukan Kota Administratif (BPS Kota Langsa, 2016).

Kota Langsa memiliki $16 \mathrm{~km}$ garis pantai yang berhadapan langsung dengan Selat Malaka dan memiliki alur-alur sungai besar membentang pada sebagian Kota Langsa sehingga dapat dilalui oleh kapal-kapal besar baik kapal nelayan penangkap ikan maupun kapal-kapal niaga yang melakukan bongkar muat barang di pelabuhan Kota Langsa. Pada awal pembentukannya, Kota Langsa hanya terdiri dari dua kecamatan yaitu Kecamatan Langsa Barat dan Kecamatan Langsa Timur.

Pada tahun 2002, terjadi pemekaran wilayah administrasi menjadi tiga kecamatan, Kecamatan Langsa Timur, Kecamatan Langsa Barat dan Kecamatan Langsa Kota, terdiri dari tiga kelurahan dan 48 desa. Selanjutnya, pada tahun 2007 berdasarkan Keputusan Walikota Langsa No. 5 terjadi pemekaran menjadi lima kecamatan, yaitu: Kecamatan Langsa Timur, Kecamatan Langsa Lama, Kecamatan Langsa Barat, Kecamatan Langsa Baro, dan Kecamatan Langsa Kota, dengan batas wilayah sebagai berikut (BPS Kota Langsa, 2018): sebelah barat berbatasan dengan Kabupaten Aceh Timur; sebelah selatan berbatasan dengan Kabupaten Aceh Timur dan Kabupaten Aceh Tamiang; sebelah timur berbatasan dengan Kabupaten Aceh Tamiang; dan sebelah utara berbatasan dengan Kabupaten Aceh Timur dan Selat Malaka.

Kota Langsa memiliki luas wilayah $239,83 \mathrm{~km}^{2}$. Luas wilayah antar kecamatan bervariasi, Kecamatan Langsa Timur dengan luas wilayah $78,26 \mathrm{~km}^{2}$ merupakan wilayah kecamatan dengan luas wilayah terbesar dibandingkan dengan kecamatan yang lain. Dari lima kecamatan yang ada di Kota Langsa, tiga kecamatan terletak di wilayah pesisir, yaitu: Kecamatan Langsa Barat, Kecamatan Langsa Timur dan Kecamatan Langsa Baro. 


\section{Kondisi Biofisik}

\section{Iklim}

Kota Langsa merupakan daerah beriklim tropis. Kondisi klimatologi Kota Langsa dapat dilihat dari data suhu udara dan curah hujan. Berdasarkan data BPS Kota Langsa tahun 2016, suhu udara Kota Langsa dalam kurun waktu 10 tahun (tahun 2005-2015) rata-rata sebesar $26,6^{\circ} \mathrm{C}$, dengan suhu maksimum terjadi pada bulan Juni yaitu $32,6^{\circ} \mathrm{C}$ dan suhu minimum terjadi pada bulan Februari yaitu $22,2^{\circ}$ C. Suhu udara Kota Langsa tahun 20052015 disajikan pada Gambar 1.

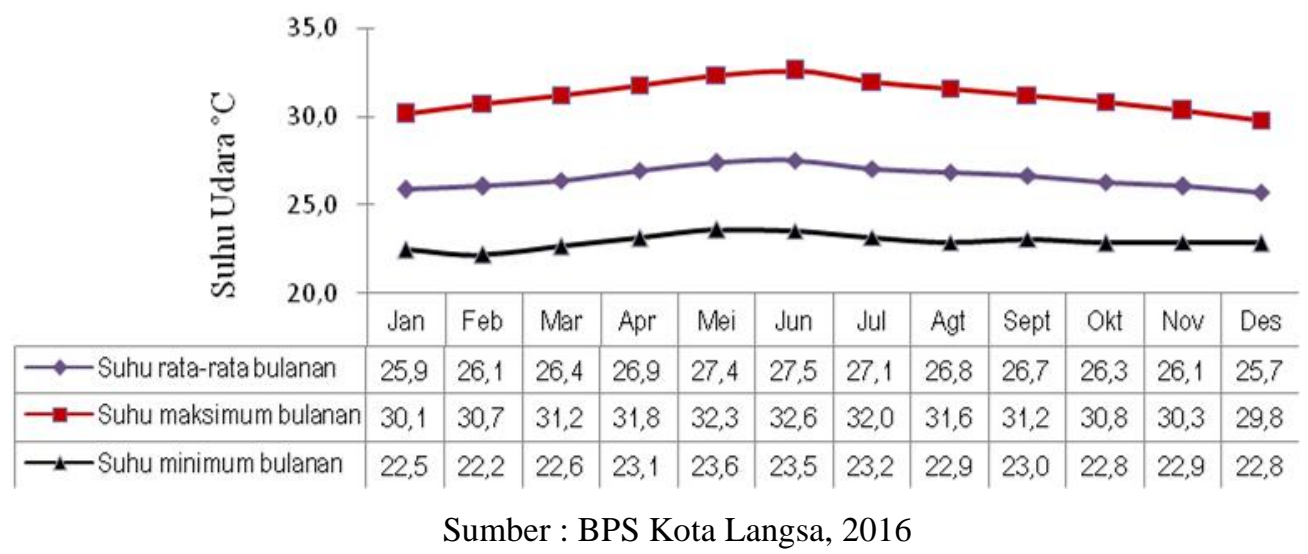

Gambar 1. Suhu udara Kota Langsa tahun 2005-2015

Curah hujan di Kota Langsa dalam kurun waktu 10 tahun (tahun 2005-2015) berfluktuasi. Curah hujan tahunan rata-rata sebesar $1.535 \mathrm{~mm}$ dengan curah hujan terendah sebesar $1.093 \mathrm{~mm}$ dan tertinggi sebesar $1.744 \mathrm{~mm}$. Curah hujan bulanan tertinggi dalam kurun waktu tersebut terjadi pada bulan Desember yaitu 255,11 $\mathrm{mm}$ dan curah hujan terendah terjadi pada bulan Februari yaitu 40,57 mm. Puncak musim hujan terjadi pada bulan OktoberNovember-Desember (OND), sedangkan puncak musim kemarau terjadi pada bulan AprilMei-Juni (AMJ) Hari hujan rata rata bulanan 13 hari, maksimum 20 hari pada bulan November dan minimum 7 hari pada bulan Februari. Berdasarkan klasifikasi iklim menurut Schmidt dan Fergusson (1956), daerah ini tergolong ke dalam tipe iklim C (agak basah) dengan nilai Q 46,34\%. Curah hujan Kota Langsa tahun 2005-2015 disajikan pada Gambar 2.

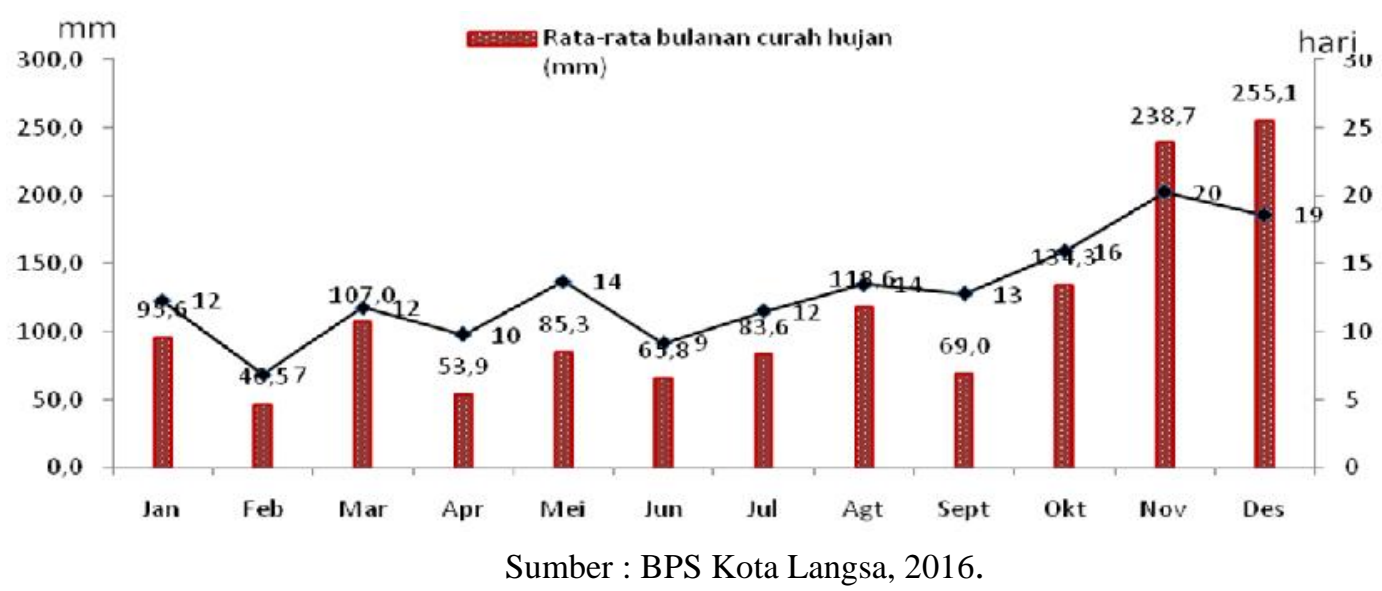

Gambar 2. Curah hujan Kota Langsa tahun 2005-2015 


\section{Kelas Lereng}

Data kelas lereng Kota Langsa diperoleh dari Peta Rupabumi skala1:50 000. Berdasarkan peta kelas lereng, kelas lereng Kota Langsa terdiri atas 4 kelas, yaitu 0-8\%, 9$15 \%, 16-25 \%$ dan 26-40\%. Kota Langsa merupakan wilayah yang terletak di kawasan pesisir, sehingga kelas lerengnya didominasi oleh kelas lereng 0-8\% dengan luas 18.371,17 ha $(91,06 \%)$. Rincian kelas lereng Kota Langsa disajikan pada Tabel 1 dan Gambar 3.

Tabel 1. Kelas lereng Kota Langsa

\begin{tabular}{ccrr}
\hline No. & Kelas Lereng $(\%)$ & Luas $(\mathrm{Ha})$ & Luas $(\%)$ \\
\hline 1 & $0-8$ & $18.371,17$ & 91,06 \\
2 & $8-15$ & 917,45 & 4,55 \\
3 & $15-25$ & 433,11 & 2,15 \\
4 & $25-45$ & 452,32 & 2,24 \\
\hline & Total & $20.174,06$ & 100 \\
\hline
\end{tabular}

Sumber : Peta Rupabumi skala 1 : 25.000 No. Lembar 1209 - 141, 142 dan 1209 - 124 Bakosurtanal tahun 2011

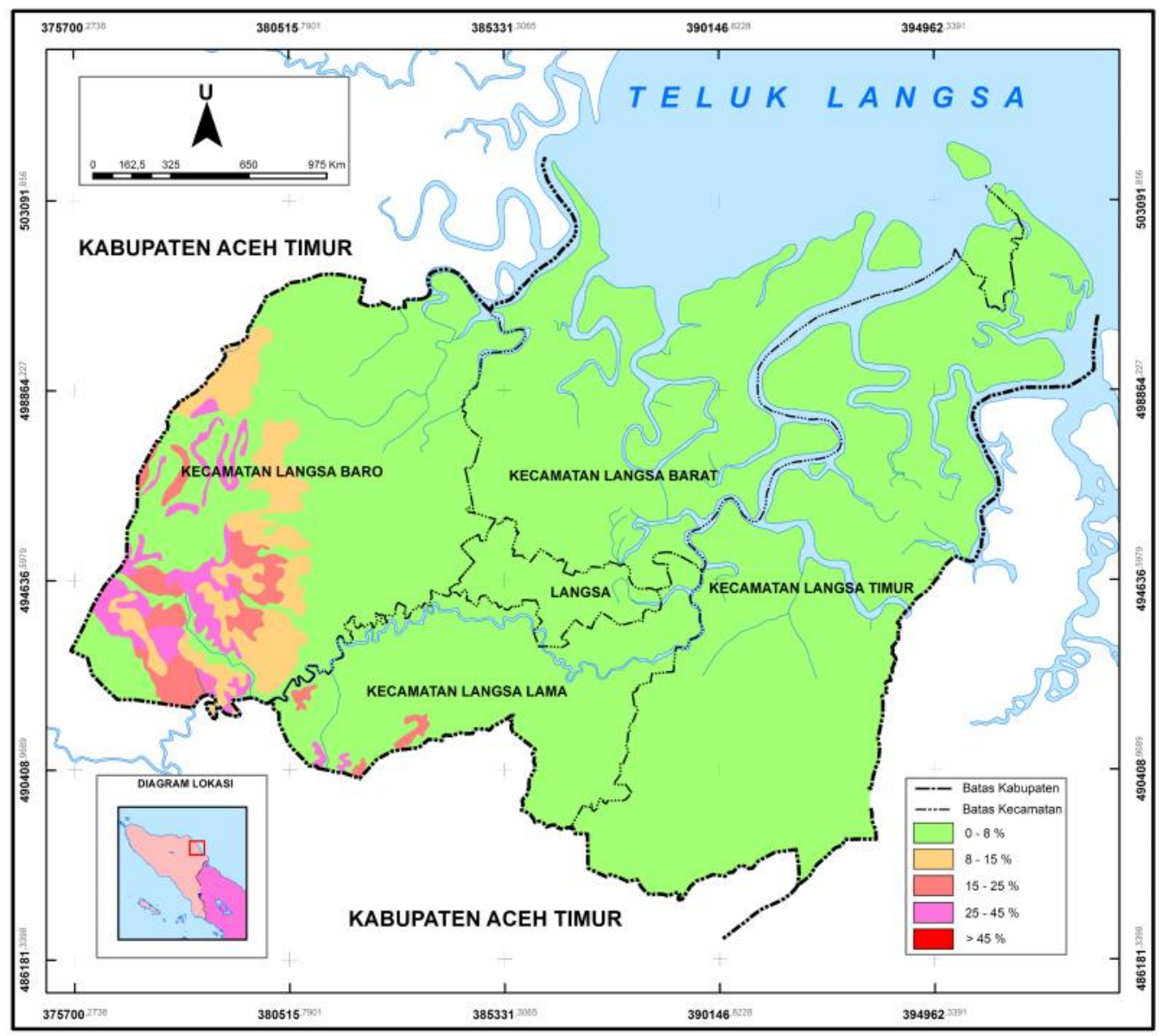

Gambar 3. Kelas lereng Kota Langsa 


\section{Jenis Tanah}

Data mengenai jenis tanah Kota Langsa diperoleh dari hasil kompilasi dari peta jenis tanah skala 1 : 250.000 (Pusat Penelitian Tanah Bogor 1983), karena di Kota Langsa belum tersedia peta tanah skala 1:50.000 sehingga sistem klasifikasinya hanya sampai pada great group saja. Ordo tanah Kota Langsa dapat digolongkan menjadi tiga, yaitu: histosol, entisol dan inceptisol.

Setelah diklasifikasikan lebih lanjut sampai dengan kategori sub-group, ordo tersebut dapat dipecah menjadi 4 great group tanah. Parameter yang membedakan diantaranya adalah perkembangan profil, warna dan tekstur. Tanah di Kota Langsa didominasi oleh ordo inceptisol dengan great grouptropaquepts dengan luas 10 558,39 ha (52,34\%). Rincian jenis tanah Kota Langsa disajikan pada Tabel 2 dan Gambar 4.

Tabel 2. Jenis tanah Kota Langsa

\begin{tabular}{clccc}
\hline No. & Ordo Tanah & Great Group Tanah & Luas (Ha) & Luas (\%) \\
\hline 1. & Inceptisol & Dystropepts & 889,24 & 4,41 \\
& & Tropaquepts & 10558,39 & 52,34 \\
2. & Histosol & Troposaprists & 4782,48 & 23,71 \\
3. & Entisol & Hydraquents & 3943,95 & 19,55 \\
\hline \multicolumn{5}{r}{} \\
\hline
\end{tabular}

Sumber: Pusat Penelitian Tanah Bogor (PPT Bogor 1983)

Penjelasan untuk masing-masing sifat ordo tanah tersebut sebagai berikut:

a) Inceptisol; merupakan tanah muda, tetapi lebih berkembang daripada Entisol. Kata Inceptisol berasal dari kata Inceptum yang berarti permulaan. Umumnya mempunyai horison kambik. Tanah ini belum berkembang lanjut, sehingga kebanyakan dari tanah ini cukup subur. Padanan dengan sistem klasifikasi lama adalah termasuk tanah Aluvial, Andosol, Regosol dan Glei humus.

Ordo tanah Inceptisol berkembang dari bahan aluvium berupa endapan liat di atas endapan pasir, reaksi tanah sangat masam sampai dengan masam, matang dan drainase terhambat. Horison A berwarna kelabu sangat gelap sampai dengan kelabu terang. Kadang-kadang terdapat karatan berwarna coklat kekuningan, tekstur liat sampai dengan liat berdebu, konsistensi lekat dan agak plaktis, reaksi tanah sangat masam sampai dengan masam. Lapisan ini mengandung bahan sulfidik (pirit) pada kedalaman $>50 \mathrm{~cm}$ dari permukaan. Dilokasi penelitian, dijumpai ordo Inceptisol yang termasuk dalam sub ordo udepts dan dua great groupyaitu dystrudepts dan tropaquepts. 


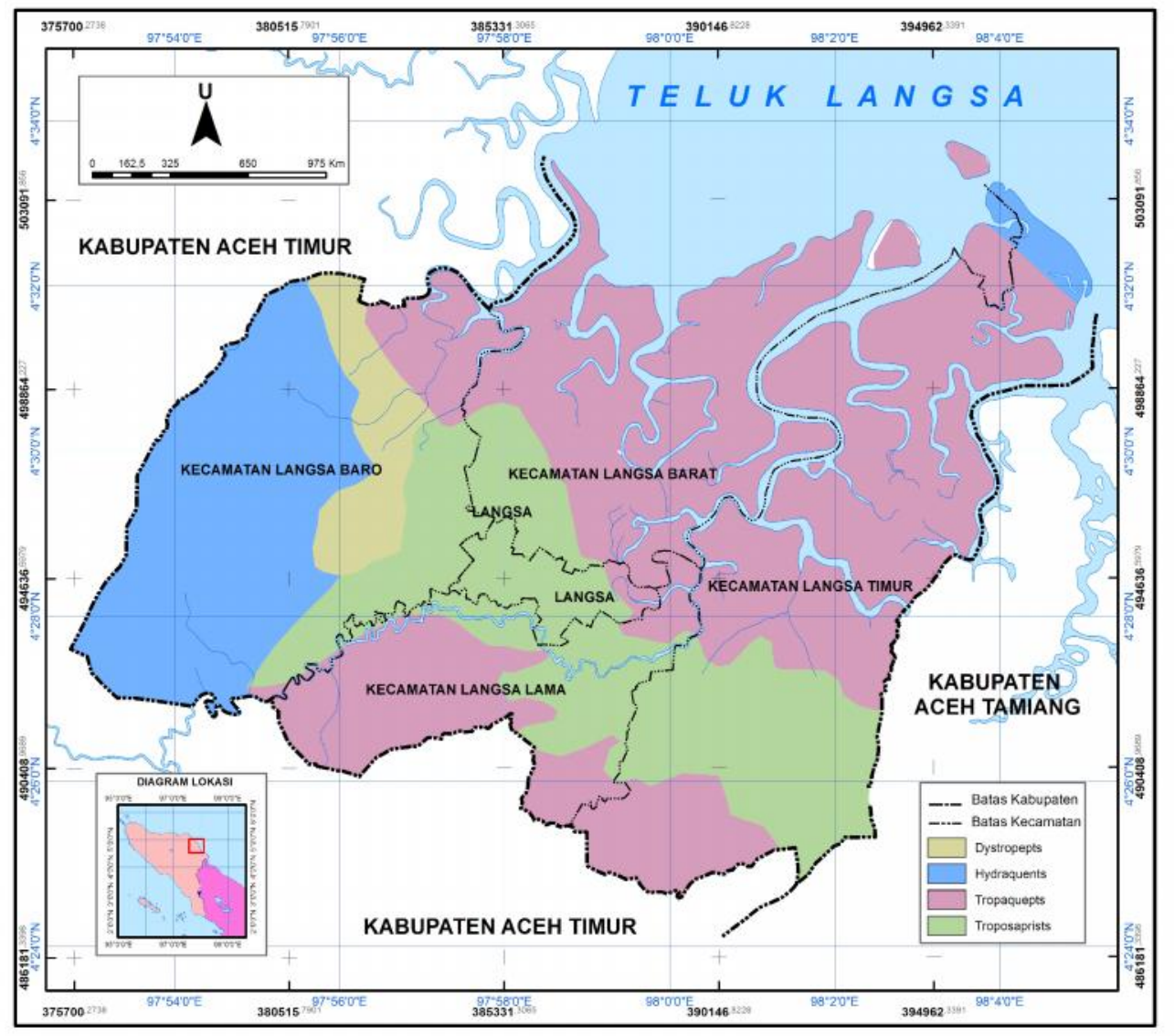

Gambar 4. Jenis tanah Kota Langsa

b) Histosol; Histosol atau Organosol atau gambut merupakan jenis tanah yang mempunyai tingkat dekomposisi saprik (heplosaprist), hemik (haplohemist) berwarna hitam sampai merah gelap, reaksi tanah masam sampai dengan sangat masam dan ketebalan gambut bervariasi dari $50 \mathrm{~cm}$ sampai dengan $>3$ meter; gambut dangkal $(50 \sim 100 \mathrm{~cm})$, gambut tengahan $(100-200 \mathrm{~cm})$, gambut dalam $(200-300 \mathrm{~cm})$ dan gambut sangat dalam $(>300 \mathrm{~cm})$. Substratum liat berwarna kelabu sampai dengan coklat gelap kekelabuan dan reaksi tanah masam. Lapisan ini terkadang mengandung pirit yang dicirikan oleh reaksi $\mathrm{H}_{2} \mathrm{O}_{2}$ kuat. Kedalaman yang mengandung bahan sulfidik bervariasi antara 100 sampai dengan $150 \mathrm{~cm}$ dari permukaan (sulfohemist). Ciri utama lainnya adalah muka air tanah yang tinggi dan sering melebihi permukaan tanah. Di lokasi penelitian dijumpai ordo Histosol yang termasuk dalam sub ordo saprist dan satu great group, yaitu troposaprists.

c) Entisol; Tanah-tanah yang termasuk dalam ordo ini merupakan tanah-tanah yang belum berkembang. Pada umumnya memiliki solum yang dangkal dengan bentukan struktur yang belum terlihat. Termasuk dalam ordo tanah ini adalah tanah-tanah yang berada pada lereng curam pegunungan, daerah endapan dan luapan sungai dan aliran lembah lahar. Ordo tanah ini berkembang dari bahan aluvium, mempunyai tingkat kematangan setengah matang (udipsamments), reaksi tanah sangat masam sampai dengan masam dan drainase terhambat (hidraquents). Tekstur bervariasi dari liat sampai dengan pasir dan umumnya liat, berwarna kelabu sangat gelap kecoklatan sampai dengan hitam. Tanah ini berada dengan luasan sedikit pada dataran banjir sungai atau laut (sulfaquents).

Tanah yang termasuk ordo Entisol merupakan tanah-tanah yang masih sangat muda yaitu baru tingkat permulaan dalam perkembangan. Tidak ada horison penciri lain kecuali epipedon ochrik, albik atau histik. Kata Ent berarti recent atau baru. Padanan dengan 
sistem klasifikasi lama adalah Aluvial atau Regosol. Dilokasi penelitian dijumpai ordo Entisols yang termasuk dalam sub ordo aquents dan satu great group, yaitu hydraquents.

\section{Tutupan Lahan}

Data base tutupan lahan lokasi penelitian diperoleh dari hasil interpretasi secara visual. Citra Satelit Landsat 7 ETM+ liputan bulan Januari tahun 2013 (Gambar 5) digunakan untuk mengetahui tutupan lahan dengan menggunakan kombinasi band 453 (false color). Hal ini bertujuan untuk mendapatkan informasi tentang liputan lahan/ penutupan vegetasi sehingga didapatkan data tutupan lahan Kota Langsa (Tabel 3 dan Gambar 6). Tutupan lahan perkebunan merupakan yang terluas yang ditemui di Kota Langsa dengan luasan 5 574,48 ha $(27,63 \%)$.

Tabel 3. Tutupan lahan di Kota Langsa

\begin{tabular}{|c|c|c|c|}
\hline No. & Tutupan Lahan & Luas (Ha) & Luas $(\%)$ \\
\hline 1 & Hutan & 1311,36 & 6,50 \\
\hline 2 & Kebun & 87,40 & 0,43 \\
\hline 3 & Kebun campuran & 476,69 & 2,36 \\
\hline 4 & Ladang/tegalan & 547,34 & 2,71 \\
\hline 5 & Pemukiman & 21,14 & 0,10 \\
\hline 6 & Lahan terbuka & 4512,78 & 22,37 \\
\hline 7 & Mangrove & 2103,02 & 10,42 \\
\hline 8 & Perkebunan & 5574,48 & 27,63 \\
\hline 9 & Sawah & 1291,13 & 6,40 \\
\hline 10 & Tambak & 4248,72 & 21,06 \\
\hline \multicolumn{2}{|r|}{ Total } & 20174,06 & 100 \\
\hline
\end{tabular}

Sumber: Analisis Citra Satelit Landsat 7 ETM+ liputan bulan Januari 2013 


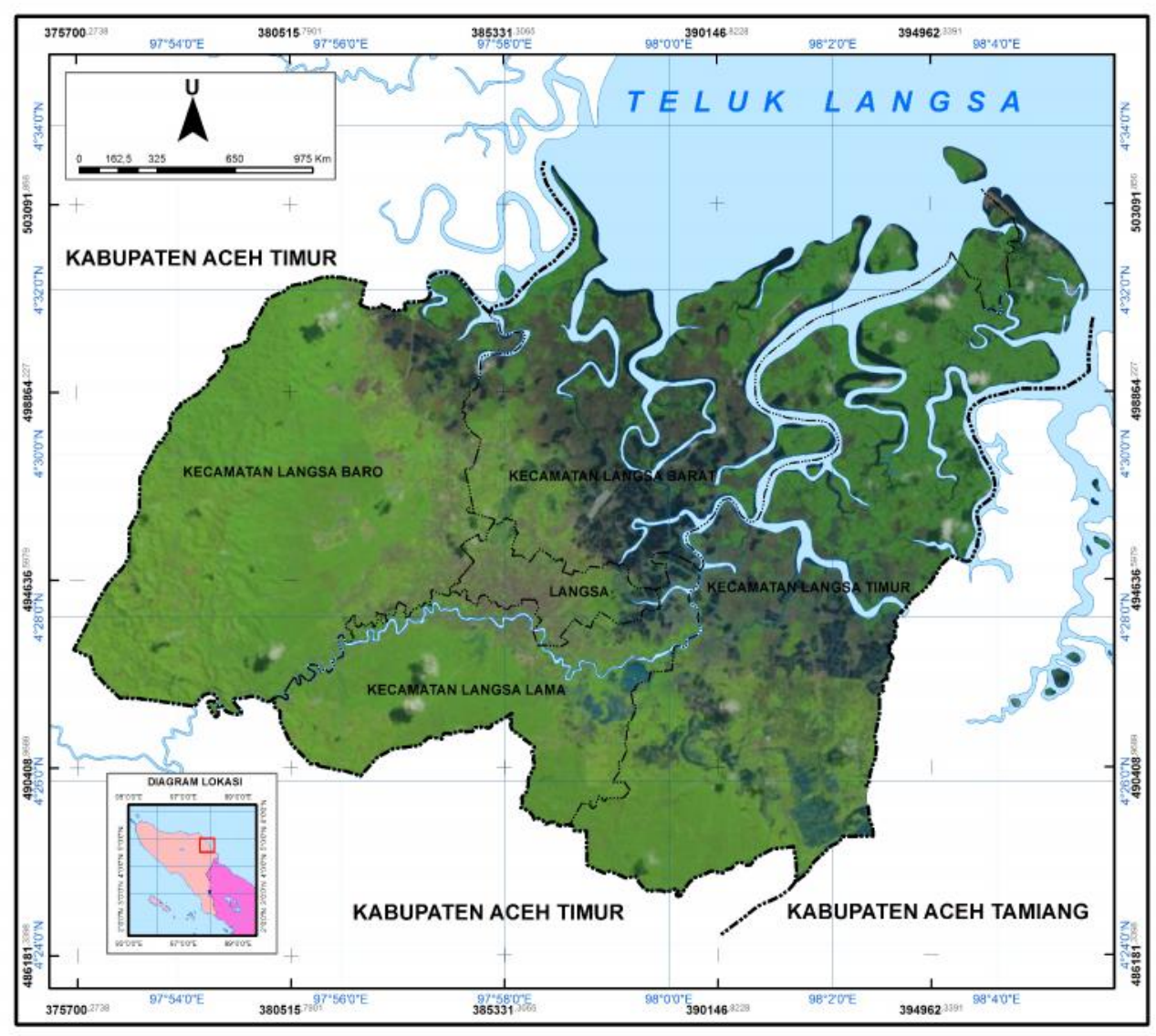

Gambar 5. Citra Landsat Kota Langsa

\section{Sistem Lahan}

Sistem lahan di Kota Langsa dideskripsikan berdasarkan Peta Sistem Lahan dari Regional Program Perencanaan Fisik untuk Transmigrasi (RePPProT) tahun 1976 dengan skala 1:250.000 (Gambar 7). Dari hasil deskripsi, didapatkan bahwa sistem lahan di Kota Langsa terdiri dari 4 (empat) jenis. Sistem lahan Bakunan (BKN) merupakan yang terluas ditemui dengan luasan 10 745,30 ha (53,26\%). Sistem lahan Kota Langsa disajikan pada Tabel 4.

Tabel 4. Sistem lahan Kota Langsa

\begin{tabular}{clrr}
\hline No. & \multicolumn{1}{c}{ Sistem lahan } & Luas (Ha) & Luas (\%) \\
\hline 1 & Bakunan (BKN) & 10745,30 & 53,26 \\
2 & Bukit Pandan (BPD) & 889,24 & 4,41 \\
3 & Kajapah (KJP) & 3757,04 & 18,62 \\
4 & Mendawai (MDW) & 4782,48 & 23,71 \\
\hline & & 20174,06 & 100 \\
\hline
\end{tabular}

Sumber : Sistem lahan dari RePProT (1976) skala 1:250.000 


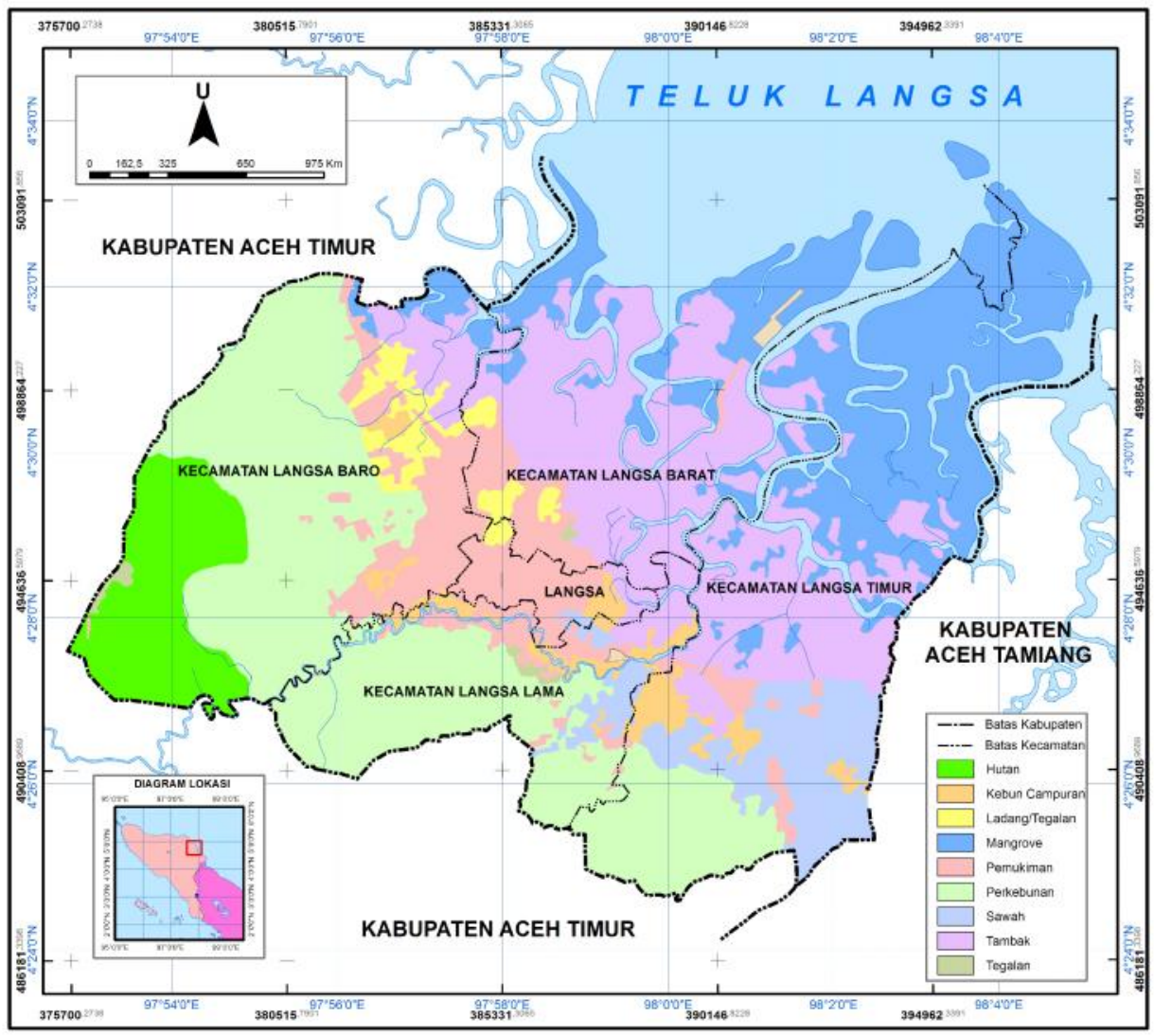

Gambar 6. Tutupan lahan Kota Langsa

Penjelasan untuk masing-masing sistem lahan di lokasi penelitian sebagai berikut:

1. Sistem lahan Kajapah (KJP) merupakan salah satu sistem lahan diwilayah pesisir yang termasuk kedalam kelompok marin. Sistem lahan KJP ini terbentuk karena proses marin, yang disebabkan oleh ombak dan angin laut. Apabila air laut memasuki daratan (lahan), maka proses geomorfologi (abrasi, sedimentasi dan intrusi) berperan aktif dan mengakibatkan perubahan bentuk lahan yang jelas. Perkembangan bentuk lahan dari kelompok ini tergolong muda dan lanjut (Desaunettes 1977).

2. Sistem lahan Bakunan (BKN) dan Mendawai (MDW) merupakan sistem lahan yang terdapat di daerah dataran dan rawa banjir. Sistem lahan BKN terjadi pada daerah lembah kecil dan dataran banjir berawa lembah sempit. Adapun sistem lahan MDW dilokasi penelitian banyak ditemui pada daerah rawa gambut dangkal terutama di daerah hilir sungai Krueng Langsa, mempunyai kemiringan rata-rata $<2 \%$, dengan batas ketinggian 110 mdpl dan jenis tanahnya troposaprists.

3. Sistem lahan Bukit Pandan (BPD) merupakan sistem lahan yang terdapat di daerah pegunungan. Bentuk lahan dari sistem pegunungan memiliki perbedaan relief lokal >300 $\mathrm{m}$ dan kemiringan lereng $>16 \%$ (Desaunettes 1977). Bentuk lahan dari sistem pegunungan ini mencakup faset lahan dari sistem yang mempunyai bahan induk batuan metamorf. Di Kota Langsa, sistem lahan ini hanya di temui di Kecamatan Langsa Baro. 


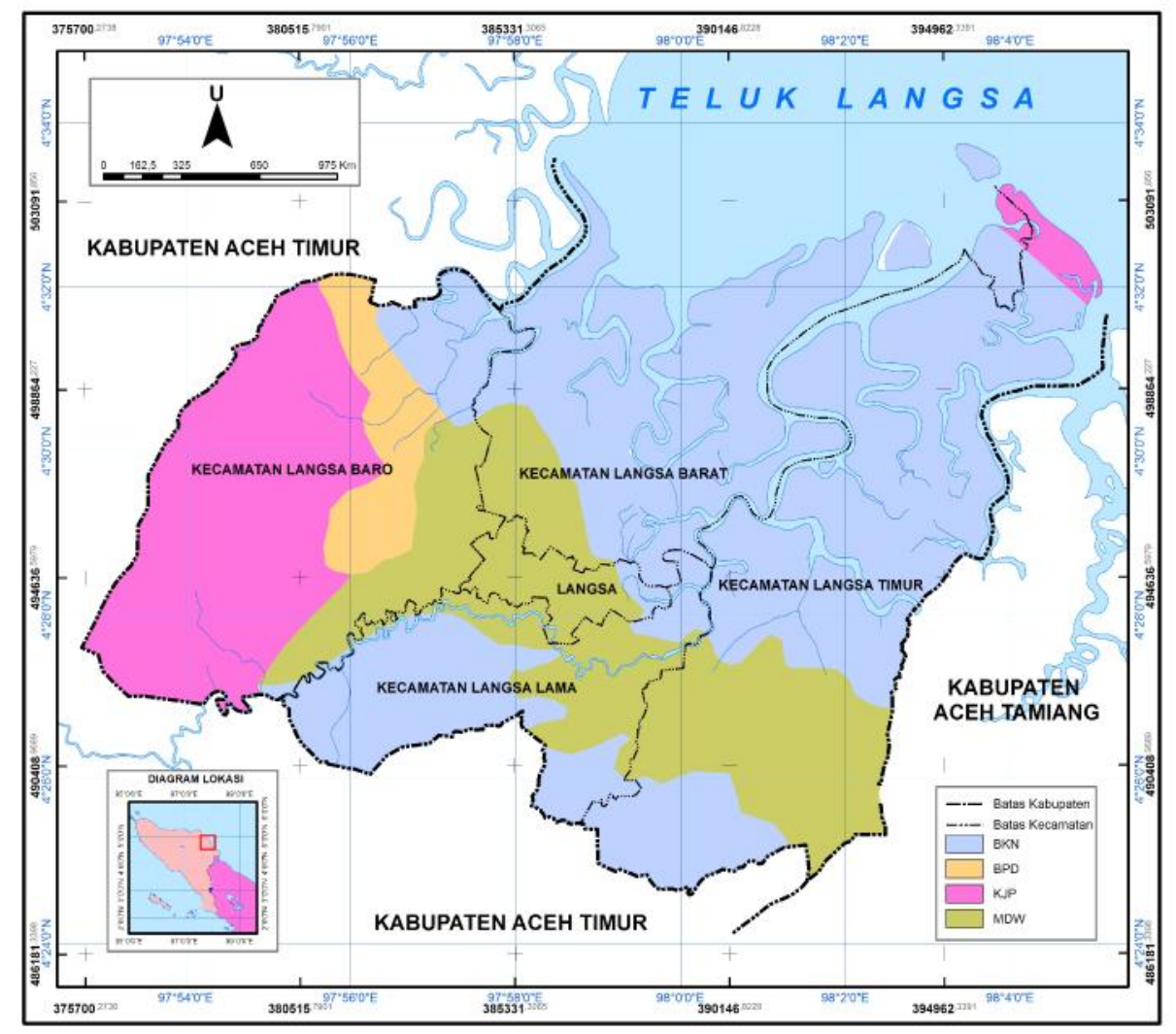

Gambar 7. Sistem lahan Kota Langsa

\section{Geologi}

Berdasarkan Peta Geologi keluaran Pusat Penelitian dan Pengembangan Geologi, Ditjen Geologi dan Sumberdaya Mineral, Departemen Pertambangan dan Energi Republik Indonesia (1992) geologi di Kota Langsa terdiri atas 4 (empat) formasi geologi. Hasil analisis menunjukkan formasi geologi Aluvium Muda (Qh) mempunyai luasan terluas dibandingkan formasi yang lain, dengan luas 12 977,64ha (64,33\%). Formasi geologi Kota Langsa disajikan pada Tabel 5 dan Gambar 8.

Tabel 5. Formasi geologi Kota Langsa

\begin{tabular}{clrr}
\hline No. & Formasi Geologi & Luas (Ha) & Luas (\%) \\
\hline 1 & Aluvium Muda (Qh) & $12.977,64$ & 64,33 \\
2 & Idi (Qpi) & $4.469,29$ & 22,15 \\
3 & Julurayeu (QTjr) & $2.357,55$ & 11,69 \\
4 & Seureula (Tps) & 369,58 & 1,83 \\
\hline & Total & $20.174,06$ & 100 \\
\hline
\end{tabular}

Sumber : Pusat Penelitian dan Pengembangan Geologi (1992) 


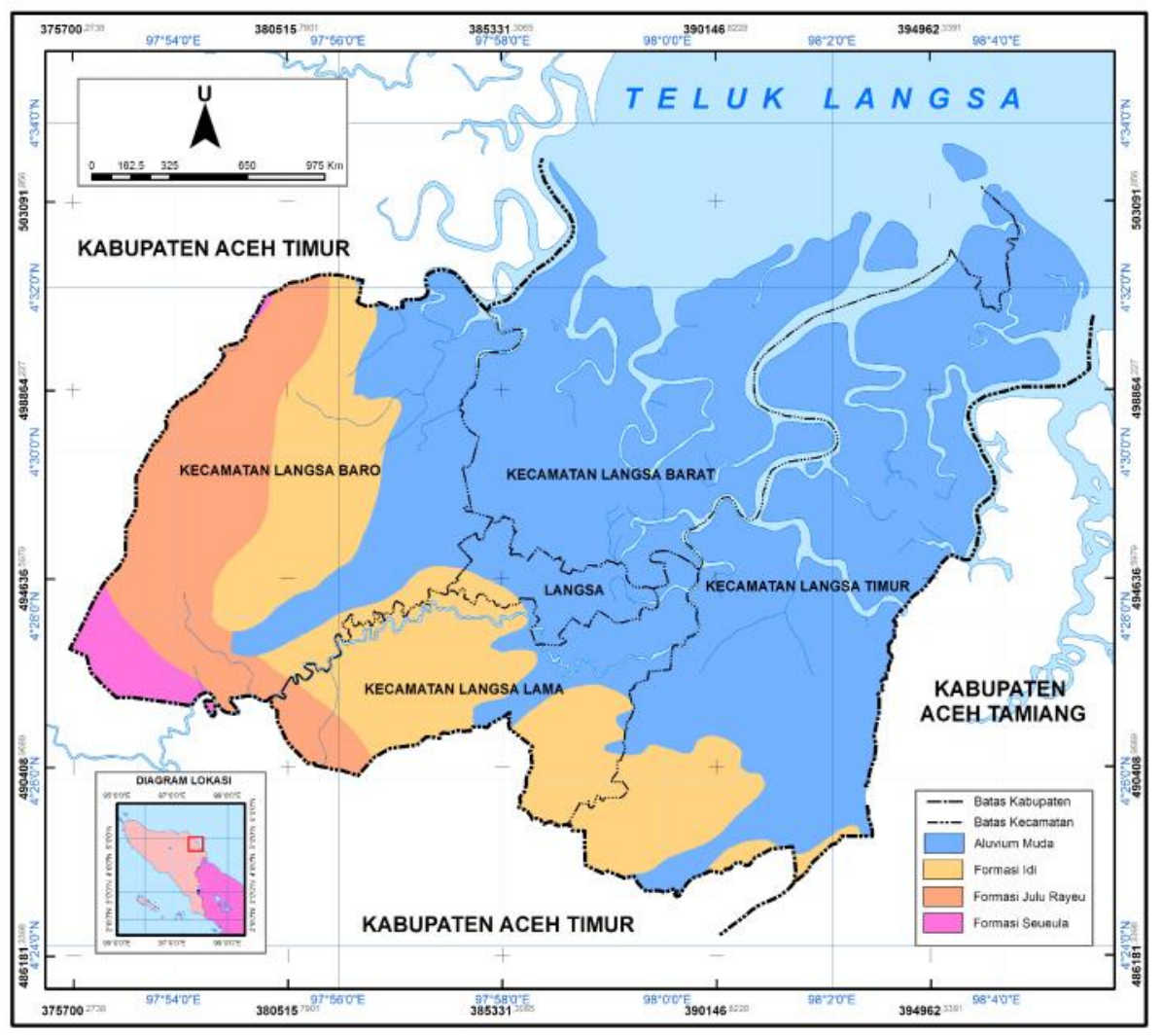

Gambar 1. Geologi Kota Langsa

Penjelasan untuk masing-masing formasi geologi sebagai berikut:

1. Formasi Julurayeu (QTjr), Berumur Plio-Pleistosen. Terdiri dari batupasir tufaan, lempung berlignit dan batulumpur serta endapan sungai. Formasi juluraye selaras dengan formasi seureula yang ada dibawahnya

2. Formasi Idi (Qpi). Berumur Pleistosen. Terdiri dari kerikil agak mampat, pasir, batugamping dan lempung.

3. Formasi Aluvium Muda (Qh), Endapan ini berumur Holosen serta terdiri dari endapan pesisir dan fluviatil. endapan aluvium pantai muda yang tersusun oleh pasir lepas. Pada akhirnya, di wilayah pesisir hingga garis pantai sekarang masih terus berkembang pembentukan endapan pantai.

4. Formasi seureula (Tps). Berumur Pliosen. Terdiri dari batupasir gunung api klastika dan batu lumpur dan batu lumpur sublitoral. Formasi seureula selaras dengan formasi juluraye yang ada diatasnya. Secara geologi ketebalan formasi ini lebih dari $1.000 \mathrm{~m}$. Formasi Seureula merupakan salah satu formasi batuan pembawa minyak dan gas bumi di cekungan sumatera bagian utara, dengan penyebaran yang relatif luas.

\section{DAFTAR PUSTAKA}

[Bakosurtanal] Badan Koordinasi Survei dan Pemetaan Nasional. 2009. Luas Kawasan Mangrove Indonesia. Bogor (ID): Bakosurtanal

[BPS] Badan Pusat Statistik Kota Langsa. 2016. Kota Langsa Dalam Angka. Langsa (ID)

[BPS] Badan Pusat Statistik Kota Langsa. 2018. Kota Langsa Dalam Angka. Langsa (ID)

Desaunettes JR. 1977. Catalogue of Landform for Indonesia. Institut Pertanian Bogor. Bogor. 
[PPT] Pusat Penelitian Tanah. 1983. Jenis dan Macam Tanah di Indonesia untuk Keperluan Survei dan Pemetaan Tanah Daerah Transmigrasi. Bogor (ID): PPT.

[PPG] Pusat Penelitian dan Pengembangan Geologi Direktorat Jendral Geologi dan Sumberdaya Mineral. 1992. Peta Geologi Indonesia. Jakarta (ID): Departemen Pertambangan dan Energi RI.

[RePPProT] Regional Physical Planning Program for Transmigration. 1990. Peta Land System RePPProT Pulau Sumatera. ODA-Bakosurtanal-Departemen Transmigrasi.

Schmidt, F. H dan Ferguson, J. H. A. 1951. Rainfall Types Based on Wet and Dry Period Rations for Indonesia With Western New Guinea. Jakarta: Kementrian Perhubungan Meteorologi dan Geofisika. 